\title{
PENGARUH KOMPENSASI FINANSIAL DAN NON FINANSIAL TERHADAP KINERJA KARYAWAN MESASTILA HOTELS DAN RESORTS
}

\author{
Margo Priyatono \\ Dosen Universitas Muhammadiyah Yogyakarta \\ Email:mpriyatono@yahoo.com
}

\section{ABSTRACT}

Histori Artikel

Submitted:

25 April 2019

Reviewed:

27 April 2019

Accepted:

30 April 2019

Published:

15 Mei 2019

This study aims to determine the effect of financial and non-financial compensation on the performance of Mesastila Hotels \& Resorts Magelang employees which are expected to be useful for management in improving the performance of their employees. This research method uses a survey approach to employees with a media questionnaire which is then analyzed by instrument and variable feasibility test, multiple linearity and different test based on employee status (fixed and contract). The results of this study indicate that financial and non-financial compensation has a significant effect on employee performance. Therefore management can provide rewards in the form of direct (financial) or indirect (non-financial) to its employees. Because someone's attitude reflects the extent to which an employee knows and is bound to his organization and reflects employee loyalty to the organization and the ongoing process in which members of the organization express their concern for the organization and continued success and progress.

Keywords: Financial compensation, non-financial compensation, performance, permanent employees, contract employees

\section{PENDAHULUAN}

Merespon perubahan pasar di semua perusahaan merupakan sesuatu yang harus dilakukan. Tanggung jawab manajer puncak adalah mengatur dan meningkatkan kinerja yang dapat membangun kekuatan untuk bertahan di pasar. Para manajer harus mengadaptasi rencana, memprediksi hasil dan merancang strategi untuk mendapatkan tingkat return yang efisien. Untuk mencapai tujuan ini manajemen harus mempertimbangkan peran SDM (karyawan) dan cara memotivasi mereka. Pengelolaan karyawan dianggap sebagai bagian penting dari strategi yang berkaitan dengan maju mundurnya perusahaan, manajer harus memastikan bahwa strategi reward (kompensasi) bagi karyawan harus dapat menantang kontribusi mereka bagi perusahaan. Jika karyawan dianggap penting oleh para manajer maka mereka akan mengarahkan perusahaan pada hasil optimal (positif), sebaliknya dapat menciptakan hasil negatif yang sulit diperbaiki dan memerlukan waktu yang relatif panjang untuk kembali pada kinerja yang diharapkan.

Bisnis perhotelan saat ini menghadapi era persaingan yang semakin ketat baik pada tingkat lokal, nasional maupun global. Dalam kondisi semacam itu salah satu upaya penting adalah pengelolaan karyawan. Tidak ada yang berani membantah bahwa karyawan adalah salah satu aset yang paling berharga yang dimiliki oleh perusahaan. Karyawan yang efektif menjadi faktor penentu sekaligus faktor kunci bagi keberhasilan perusahaan.

Di Magelang, bisnis perhotelan mengalami pertumbuhan yang pesat, pesatnya pertumbuhan ini akan mengahantarkan bisnis ini pada tingkat persaingan yang semakin ketat, ketatnya persaingan ini tentu saja membutuhkan karyawan yang memiliki kinerja yang lebih baik. Karyawan menjadi generator penting dalam menggerakkan operasional bisnis perhotelan yang lebih 
efisien. Kinerja bisnis perhotelan berada ditangan karyawan yang cerdas, trampil, bersemangat dan berkomitmen tinggi yang melahirkan sejumlah prestasi kerja yang lebih unggul, terutama ketika manajemen mampu menciptakan situasi dan kondisi yang dapat mendorong karyawan bekerja secara optimal.

Keberadaan karyawan yang handal memiliki peran strategis dalam menggerakkan bisnis jasa perhotelan. Untuk mempertahankan kelangsungan dan kemajuan usaha perhotelan, manajemen harus memberikan perhatian kepada karyawan. Karyawan, dalam kapasitasnya sebagai pekerja harus dijadikan sebagai mitra internal bisnis, dan di saat yang sama, manajemen harus bersikap adil terhadap kontribusi mereka kepada perusahaan, setiap karyawan pasti ingin mendapatkan kompensasi, penghargaan dan perlakuan yang adil terhadap pekerjaannya.

Karyawan akan

bekerja secara maksimal untuk meningkatkan kinerjanya guna mendapat kompensasi yang sesuai. Kinerja karyawan merupakan ukuran terhadap hasil kerja baik secara kualitas maupun kuantitas pekerjaan yang dinyatakan dalam kurun waktu tertentu dan karenanya mereka diberi konpensasi baik finansial maupun nonfinasial.

Konpensasi finansial diberikan kepada karyawan atas hasil kerjanya dan biasanya diberikan dalam bentuk uang (gaji), bonus, komisi, pembagian laba, dan kompensasi yang ditangguhkan, jaminan sosial seperti penyediaan rumah tinggal (dengan cara diangsur), tunjangan lembur, tunjangan kesehatan dan lainnya.

Kompensasi non finansial dapat diberikan dalam bentuk piagam penghargaan, pemberian pujian lisan ataupun tertulis, ucapan terima kasih secara formal maupun informal, promosi jabatan, pemberian tanda jasa kepada karyawan yang telah mencapai masa kerja yang cukup lama, mempunyai loyalitas yang tinggi, pemberian hak untuk menggunakan atribut jabatan (misalnya mobil atau lainnya), pemberian tugas-tugas baru atau tantangan yang menarik, mitra kerja yang menyenangkan, atau pemberian perlengkapan khusus pada ruang kerja, lingkungan kerja yang nyaman dan sebagainya.

Perusahaan mengkategorikan proses kompensasi langsung dan tidak langsung yang diperkirakan akan mempengaruhi kinerja. Oleh karena itu, karyawan yang menikmati kompensasi langsung (gaji/upah) sebagai hasil dari menyelesaikan tugasnya berhasil dengan baik. Demikian juga kompensasi tidak langsung seperti tunjangan, kondisi kerja, keamanan kerja, promosi, lingkungan pekerjaan dan imbalan emosional misalnya pengakuan, penghargaan dan kepuasan atas pekerjaaannya (Almutairi, et al. 2013)

Pemberian kompensasi diyakini dapat meningkatkan kinerja karyawan. Oleh karena itu, pengaturan konpensasi yang rasional dan adil menjadi penting, terutama dalam kaitannya dengan upaya memelihara dan mempertahankan kinerja karyawan. Bila karyawan memandang pemberian kompensasi tidak memadai, kinerja mereka cenderung akan menurun, demikian juga sebaliknya.

Kompensasi dan kinerja secara langsung akan menentukan keberadaan perusahaan sekarang maupun keberlanjutannya dimasa mendatang. Oleh karena itu masalah utama penelitian ini apakah kompensasi finansial dan non finansial berpengaruh positif terhadap kinerja karyawan tetap dan karyawan kontrak di Mesastila Hotels \& Resorts. Hasilnya dapat digunakan sebagai (a) salah satu referensi alternatif dalam upaya pembinaan karyawan/SDM yang ada dalam meningkatkan kinerja atau sebagai pembanding sesuai dengan bidang yang akan diteliti, (b) memberikan sumbangan pemikiran, menambah wawasan pengetahuan serta memberikan bukti empiris dari penelitian-penelitian sebelumnya terutama yang berkaitan dengan pengaruh kompensasi finansial dan nonfinansial terhadap kinerja karyawan dalam baik industri jasa maupun industri manufaktur; (c) dapat dijadikan sebagai bahan evaluasi tentang sejauh mana pelaksanaan program kompensasi dapat meningkatkan kinerja karyawan; (d) dapat menjadi pertimbangan dalam dua kondisi 
yang berbeda : (1) mempertahankan sistem kompensasi nonfinansial yang saat ini telah diberikan jika sistem tersebut mampu meningkatkan kinerja karyawan atau (2) memperbaiki sistem kompensasi finansial jika sistem yang sekarang kurang mampu meningkatkan kinerja karyawan.

\section{LITERATUR REVIEW \\ Kinerja Karyawan}

Konsep kinerja dikaitkan dengan akurasi, kuantitas output, kualitas output, ketepatan waktu, kehadiran pekerjaan, efisiensi pekerjaan dan efektifitas kerja. Kinerja setiap individu (individual performance) dengan kinerja perusahaan (corporate performance) tidak bisa dipisahkan. Artinya jika kinerja perorangan baik, maka kinerja perusahaan juga akan baik, demikian juga sebaliknya. Kinerja perusahaan adalah akumulasi dari kinerja individual. Seberapa tinggi kinerja peusahaan sangat tergantung kualitas dan kuantitas yang dicapai oleh seorang karyawan. dalam melaksanakan tugas sesuai dengan tanggung jawab yang diberikan kepadanya.

Hameed dan Waheed (2011) menjelaskan bahwa kinerja karyawan berarti produktivitas dan output karyawan sebagai hasil dari pengembangan karyawan, kinerja karyawan pada akhirnya akan mempengaruhi efektivitas organisasi. Ini berarti bahwa hasil kerja yang dicapai oleh seorang karyawan dalam melaksanakan tugas dan tanggung jawabnya harus terukur dan dapat dinyatakan baik secara kualitas dan kuantitas

Umumnya pengukưran kinerja dimaknai sebagai proses menilai kemajuan yang sebenarnya dalam mencapai standar kinerja dasar (baseline) yang dicapai oleh setiap karyawan baik dalam ukuran kuantitatif maupun kualitatif. Makna penting dari setiap pengukuran kinerja baik bagi manajemen dan karyawan paling tidak :

1. Karyawan dapat meningkatkan pemahaman tentang persyaratan kinerja yang diperlukan oleh perusahaan;

2. Karyawan dapat meningkatkan pemahaman terhadap catatan kerja harian (logbook) yang dilakukannya dan hasil yang mereka capai, sehingga memberi peluang dan termotivasi untuk berbuat yang lebih baik untuk masa-masa mendatang;

3. Manajemen dapat merumuskan kembali sasaran masa depan, sehingga karyawan termotivasi untuk berprestasi sesuai dengan potensinya.

4. Manajemen dapat memeriksa rencana pelaksanaan dan pengembangan kebutuhan pelatihan untuk meningkatkan kualitas dan profesionalisme karyawan.

Iveta (2012) menjelaskan bahwa indikator penilaian kinerja harus terkait dengan semua tujuan dalam peta strategi perusahaan. Hal ini penting untuk menetapkan nilai strategis yang diperlukan untuk mengekspresikan kekuatan kinerja organisasi secara keseluruhan yang terhubung dengan indeks kualitatif karyawan. Menurut Monil dan Tahir (2011) bahwa indikator kualitatif karyawan hotel paling tidak mencakup kemampuan menginformasikan fasilitas hotel, kemampuan membuat kontak dengan pelanggan, kemampuan dalam menyampaikan informasi reservasi - harga, kemampuan dalam pengelolaan pelanggan, kemampuan berkomunikasi dengan pelanggan, kesetiaan, tanggung jawab dalam melaksanakan tugas, kejujuran, kemampuan kerja sama, prakarsa - kreativitas dan kepemimpinan. Sementara kualifikasi kuantitatif karyawan hotel berkaitan dengan level produksi, kualitas pekerjaan, kemampuan menyelesaikan pekerjaan, kemampuan merawat dan memperbaiki peralatan kerja.

\section{Kompensasi}

Karyawan harus menyadari bahwa imbalan tergantung pada kinerja mereka, demikian juga penghargaan secara langsung terkait dengan tingkat kinerja. Gohari, et, al (2013) menegaskan bahwa karyawan harus tahu bahwa mereka memiliki kemampuan yang dibutuhkan atau keterampilan untuk tampil di tingkat pekerjaan yang diperlukan dalam perusahaan. Jika mereka tidak percaya itu, penghargaan tidak akan membantu meningkatkan kinerja mereka. Bentuk valid dan arah sistem imbalan harus dikaitkan 
dengan upaya memotivasi kinerja karyawan dan ini dapat diandalkan sebagai salah satu strategi perusahaan, meningkatkan keterampilan, menarik dan mempertahankan mereka.

Sultana et al (2012) mendefinisikan salary atau kompensasi sebagai penghargaan atau imbalan dalam bentuk uang dan non-uang yang disediakan oleh perusahaan atas waktu, keahlian, keterampilan dan upaya yang dilakukan oleh karyawan dalam memenuhi persyaratan pekerjaan yang bertujuan untuk mencapai tujuan bisnis.

Sajuyigbe, Bosede dan Adeyemi (2013), menjelaskan bahwa karyawan akan melihat sistem penghargaan dan kompensasi didasarkan pada teori harapan, yang menunjukkan bahwa karyawan lebih cenderung termotivasi untuk melakukan pekerjaanya ketika mereka melihat ada hubungan yang kuat antara kinerja dan penghargaan yang mereka terima. Sejalan dengan pemikiran di atas, menurut Fatai et al (2013), ketika penghargaan dan pengakuan yang efektif diterapkan dalam sebuah perusahaan, dan lingkungan kerja yang menguntungkan dapat memotivasi karyawan untuk unggul dalam kinerja mereka. Karyawan menggunakan pengakuan sebagai keterikatan perasaan terhadap nilai dan apresiasi, dan sebagai hasilnya akan meningkatkan moral karyawan yang pada akhirnya akan meningkatkan produktivitas karyawan. Kompensasi memainkan peran penting dalam menentukan kinerja yang signifikan dalam pekerjaan dan secara positif terkait dengan proses motivasi kerja.

Ali dan Ahmed (2009) mengkonfirmasi bahwa reward, dan pengakuan dapat meningkatkan kepuasan dan motivasi kerja. Itu berarti, jika reward dan pengakuan yang ditawarkan kepada karyawan itu berubah, maka akan terjadi perubahan dalam motivasi kerja dan kepuasan. Sebuah rencana insentif akan memiliki pengaruh positif pada penjualan, keuntungan dan kepuasan pelanggan. Karyawan yang berpenghasilan rendah akan termotivasi secara intrinsik (dari dalam diri sendiri), demikian juga karyawan dengan pendapatan yang lebih tinggi akan menempatkan nilai yang lebih besar pada motivasi intrinsiknya.

Ini menunjukkan dengan jelas bahwa nilai ekonomi akan menempatkan posisi seseorang pada faktor ekstrinsik (dari luar individu) dalam bentuk kompensasi : (1) sebagai salah satu kunci yang memotivasi karyawan untuk melakukan seperti yang diharapkan (2) berupa uang, pengakuan dan pujian atau kombinasi keduanya dapat di design untuk mencapai sasaran atau tujuan perusahaan, untuk meningkatkan produktivitas dengan menyelaraskan kepentingan karyawan dengan kinerja keuangan perusahaan, (3) kompensasi sebagai sistem yang menghubungkan kepentingan karyawan untuk meningkatkan usaha dan kinerja, artinya bahwa kinerja sebagai hasil dari sebuah pekerjaan adalah hasil dari kemampuan dan motivasi, (4) secara tidak langsung dipenuhi melalui penggunaan kompensasi akan menjadi insentif yang ideal bagi karyawan sebaliknya mengabaikan kompensasi, perusahaan harus siap dengan penurunan kinerja jangka pendek maupun jangka panjang, (5) mampu memerangi kelelahan, yang biasanya dialami oleh sebagian besar karyawan. Individu yang mengalami kehabisan energi dalam pekerjaannya, cenderung memiliki pandangan negatif, kurang bersemangat dan dedikasinya menjadi rendah, (6) kompensasi yang buruk terkait dengan keuntungan yang dibuat oleh perusahaan. Upah diferensial pada posisi rendah terkait dengan moral yang rendah, kurangnya komitmen dan produktivitas yang rendah (7) kompensasi yang diberikan harus dapat mengikat para karyawan, jika terlalu kecil dibandingkan usahanya atau perusahaan lainnya, dapat menyebabkan karyawan pindah ke perusahaan yang lain atau berperilaku negatif. Oleh karena itu, pengaturan kompensasi secara benar dan adil adalah inti dari manajemen peningkatan kinerja karyawan.

Wiese dan Coetzee (2013), menggolongkan penghargaan ke dalam dua kelompok, yaitu : Penghargaan intrinsik berupa rasa puas diri yang diperoleh seseorang yang telah berhasil menyelesaikan pekerjaannya dengan baik dan telah mencapai 
sasaran tertentu, misalnya dengan penambahan tanggung jawab, pengayaan pekerjaan (job enrichment) dan usaha lain yang meningkatkan harga diri sesorang dan yang mendorong orang untuk menjadi yang terbaik. Penghargaan ekstrinsik terdiri dari kompensasi yang diberikan kepada karyawan baik berupa kompensasi finansial seperti gaji, honorarium dan bonus, penghargaan tidak langsung seperti asuransi kecelakaan, honorarium liburan dan tunjangan masa sakit serta penghargaan nonkeuangan berupa ruang kerja yang memiliki lokasi istimewa, peralatan kantor yang istimewa, tempat parkir khusus, gelar dan sekretaris pribadi.

Menurut Sunil dan Nitin (2012), gaji merupakan faktor motivasi yang paling jelas ketika datang ke pekerjaan. Karyawan terus bersaing untuk posisi yang menawarkan akses reward tercepat. Kadang-kadang, banyak faktor motivasi lain untuk mencapai kepuasan kerja. Itu sebabnya setiap kali mendapat gaji yang baik dihotel lain atau sektor jasa lain mereka akan berpindah tempat kerja.

Gaji, adalah pertimbangan manajemen dalam memberikan penghargaan nyata kepada karyawan dalam bentuk uang untuk memenuhi kebutuhan dasar hidup yang memotivasi orang bekerja. Bahkan sering, uang dipandang sebagai simbol kesuksesan pribadi dan prestasi Wiese dan Coetzee (2013), Said and Muammer (2010) mengemukakan bahwa bentuk kompensasi yang diberikan perusahaan kepada karyawan dapat dikelompokkan menjadi kompensasi finansial dan kompensâsi nonfinansial.

\section{Kompensasi Finansial}

\section{Kompensasi finansial langsung} merupakan bentuk pemberian imbalan yang diberikan kepada seseorang secara langsung dalam bentuk gaji yang sifatnya tetap berdasarkan tenggang waktu yang tetap, sementara bonus, atau komisi diberikan berdasarkan kinerja tertentu dalam waktu tertentu, demikian juga penghargaan diberikan untuk memotivasi para pekerja agar produktivitas kerjanya tinggi yang sifatnya tidak tetap atau sewaktu-waktu.

Kompensasi finansial tidak langsung ini merupakan pemberian dari bagian keuntungan/man-faat bagi para pekerja di luar gaji atau upah tetap, dapat berupa uang atau barang, tunjangan, meliputi semua imbalan finansial yang tidak mencakup dalam kompensasi finansial langsung seperti program asuransi tenaga kerja atau jaminan sosial tenaga kerja (jamsostek), jaminan hari tua, asuransi kesehatan, bantuan biaya pengobatan (jika sakit), cuti dan lain-lain.

\section{Kompensasi Nonfinansial}

Konpensasi nonfinancial sering menjadi efektif untuk menghasilkan pengaruh yang kuat, terutama ketika dimensi kerja (tantangan, variasi, umpan balik dan otonomi), karakteristik kepemimpinan (dukungan dan kepercayaan) kondusif untuk meningkatkan kinerja karyawan. Dalam pandangan Wiese dan Coetzee (2013) kompensasi nonfinansial berkaitan dengan kepuasan seseorang terutama yang berhubungan dengan (a) Pekerjaan: tugastugas yang menarik, tantangan dan tanggung jawab baru, kesempatan untuk menjadi kreatif dalam pekerjaan sehari-hari, pengakuan atas usaha dan prestasi, peluang kemajuan untuk belajar hal-hal baru, kemungkinan dipromosikan dan keterlibatan dalam penetapan target kerja, (b) Lingkungan kerja: kebijakan kerja, pengawasan berkompeten, teman sekerja yang menyenang-kan, kondisi kerja nyaman dan aman,

Besar kecilnya kompensasi yang diterima karyawan mencerminkan status, pengakuan dan tingkat pemenuhan kebutuhan yang dinikmati oleh karyawan. Jika kompensasi yang diterima karyawan semakin besar, berarti jabatannya semakin tinggi, statusnya semakin baik, dan pemenuhan kebutuhan yang dinikmatinya semakin banyak pula. Apabila kompensasi yang diterima karyawan (kompensasi finansial dan nonfinansial) semakin besar maka kinerja karyawan semakin tinggi, sebaliknya apabila kompensasi yang diterima karyawan (kompensasi finansial dan nonfinan-sial) semakin rendah, maka kinerja karyawan juga rendah. Disinilah letak pentingnya kompensasi bagi karyawan (fisik dan pikiran). 
Menurut Sajuyigbe et al, (2012) bahwa insentif keuangan (gaji) memiliki kekuatan membangun kinerja karyawan. Pujian, pengakuan dan imbalan dari perusahaan (faktor intrinsik) paling efisien dalam meningkatkan kinerja karyawan. Reward menjadi alat penting dalam memotivasi karyawan untuk melakukan seperti yang diharapkan perusahaan.

Dari uraian diatas dapat dipahami bahwa gaji yang tinggi dapat menginspirasi seseorang untuk termotivasi sampai batas tertentu. Di luar itu, seperti aktualisasi diri mungkin diperlukan untuk menjaga agar karyawan tetap loyal dan bergairah dalam bekerja. kompensasi nonfinasial biasanya terkait dengan manfaat yang diterima oleh karyawan di samping gaji pokok yang sebenarnya diterima. Imbalan keuangan dapat mencakup (a) kinerja yang terkait dengan imbalan seperti komisi, bonus kinerja, penghargaan prestasi, saham, dan penghargaan prestasi lainnya (b) penghargaan keanggotaan seperti tunjangan pensiun, asuransi kesehatan, liburan, subsidi kantin (makan siang), tunjangan kendaraan atau alokasi sarana komunikasi. Sementara Penghargaan non-finansial dapat meliputi (a) status penghargaan seperti lokasi kantor utama, pilihan perabot, area parkir yang disediakan, asisten pribadi atau pengakuan public (b) penghargaan sosial seperti pujian, undangan makan malam dan keterlibatan aktif dalam kegiatan sosial. $\mathrm{Di}$ sisi lain, penghargaan kompensasi yang secara langsung dikaitkan dengan persyaratan pekerjaan itu sendiri, dan memiliki efek jangka panjang,"seperti (a) meningkatkan tanggung jawab (b) pemberdayaan (c) partisipasi yang lebih besar dalam keputusan yang dibuat dalam organisasi (b) peluang untuk pertumbuhan dan kemajuan individu.

Dengan demikian, bahwa imbalan finansial murni saja tidak menjamin berkelanjutan kinerja karyawan dalam jangka panjang. Sistem penghargaan dalam penelitian ini fokus pada kompensasi finansial dan kompensasi nonfinansial. kompensasi finansial terdiri dari gaji, bonus dan tunjangan dapat meningkatkan kinerja karyawan.
Demikian juga dengan kompensasi nonfinansial yakni kondisi pekerjaan dan lingkungan dapat meningkatkan kinerja karyawan. Pemberian tanggung jawab yang lebih besar, promosi, pengambilan keputusan atau kemajuan karir jangka panjang justru menjadi penting di tempat kerja.

\section{Karyawan Tetap dan Karyawan Kontrak}

Dalam semua kasus kinerja perusahaan sangat ditentukan oleh kinerja karyawan, oleh karena itu, perekrutan harus membawa kualitas orang yang sesuai dengan kebutuhan organisasi, pelatihan harus meningkatkan pengetahuan dan kemampuan karyawan; evaluasi kinerja harus membatasi perbedaan antara karyawan, dan kegiatan promosi harus memajukan bakat dan kemampuan di tangga organisasi (Mutua et al, 2013).

Perhatian untuk meningkatkan kinerja bisnis harus bersamaan dengan peningkatan perhatian terhadap potensi karyawan sebagai sumber keberlanjutan peningkatan kinerja dan power karyawan dalam membangun keunggulan kompetitif perusahaan (Voorde, Pauwe dan Veldhoven, 2010).

Caliskan (2010) menjelaskan bahwa para akademisi berusaha untuk membuktikan bahwa pengelolaan karyawan memiliki pengaruh positif pada produktivitas karyawan dan kinerja bisnis, selain itu hasil capaian nilai uang sering digunakan sebagai alat ukur, kegagalan mengukur kebijakan karyawan, pengawasan, kelalaian, dan potensi kegagalan. Umpan balik pengukuran sangat penting untuk memperbaiki dan mengembangkan ide pelaksanaan serta mempelajari seberapa baik praktek pengelolaan yang sebenarnya dapat mencapai hasil yang diinginkan. Karena itu, jika kisaran kebijakan karyawan itu tepat, prosesnya dikembangkan dan diimplementasikan secara efektif, maka karyawan akan membuat pengaruh besar pada kinerja bisnis.

Karyawan Tetap, merupakan elemen dasar hotel yang dibutuhkan untuk melaksanakan tugas yang berkaitan dengan operasional hotel, dan tidak didasarkan pada tinggi-rendahnya tingkat occupancy hotel. 
Karyawan tetap dipekerjakan oleh perusahaan tidak ada batasan jangka waktu lamanya bekerja. Karyawan tetap yang bekerja dalam sebuah perusahaan cenderung lebih merasa aman, sebab kepastian masa depan sangat ditentukan oleh sikap positif yang ditunjukkan selama bekerja dan tidak dibebani oleh waktu atau masa kontrak.

Salah satu faktor yang akan membuat karyawan termotivasi dalam bekerja adalah pencapaian jenjang karier atau jabatan di perusahaan, sebaliknya, jika sikap positif yang ditunjukkan karyawan tetap dalam bekerja sangat minim, maka motivasi berprestasi karyawan tetap tersebut menjadi sangat rendah dan tentunya kinerja karyawan tersebut menjadi sangat rendah. Adanya rasa aman menjadi karyawan tetap, tidak jarang menjadikan karyawan yang bersangkutan tidak terpacu dengan target-target perusahaan. Kondisi ini menciptakan situasi tidak produktif dan sangat berpengaruh terhadap capaian target dan produktivitas perusahaan.

Sekarang ini, banyak perusahaan memenuhi kebutuhan tenaga kerjanya menggunakan model kontrak (outsourcing) dalam perekrutan tenaga kerja. Sistem outsourcing pada awalnya diterapkan untuk perusahaan manufaktur, tetapi akhir-akhir ini perusahaan jasa juga menggunakan model ini. Sopiah (2013) merekomedasikan bahwa perusahaan yang mengadopsi penggunaan model tenaga kerja outsourcing sebaiknya dilakukan secara langsung (jangan menggunakan asosiasi atau perusahaan penyalur tenaga kerja) agar tidak merugikan karyawan misalnya pemotongan upah atau gaji karyawan pada saat penerimaan kerja. Selain itu, dalam waktu yang ditentukan karyawan dapat direkrut sebagai karyawan tetap jika memenuhi persyaratan atau standar kinerja yang ditetapkan oleh perusahaan.

Karyawan kontrak adalah karyawan yang dipekerjakan dengan status kontrak dan sebelumnya telah diatur tugas, wewenang dan tanggung jawabnya melalui perjanjian selama waktu tertentu. Ada dua jenis karyawan kontrak. Pertama, outsourcing dengan lama waktu dua tahun, dapat diperpanjang untuk satu tahun dan maksimal satu kali, setelah perpanjangan, karyawan ini dapat diangkat menjadi karyawan tetap sesuai dengan prosedur, kriteria dan kebutuhan hotel. Kedua, adalah karyawan casual yang waktunya sangat terbatas, umumnya antara 3 sampai 6 bulan.

Munch (2010) mengekplorasi pengaruh negatif kehadiran karyawan kontrak sebagai berikut: Pertama, kepuasan kerja dapat menurun sebagai akibat dari ketidakpastian masa depan. Kedua, meningkatnya kekhawatiran atas keberlanjutan pekerjaan. Ketiga, meningkatkan risiko pengangguran pekerja berketerampilan rendah karena perusahaan akan cenderung menggunakan karyawan kontrak terhadap karyawan yang berketerampilan tinggi. Keempat, penurunan promosi bagi karyawan tetap, posisi tawar dan voice mereka menjadi lemah. Kelima, outsourcing dapat mendorong perampingan di beberapa pekerjaan, dengan intensitas hasil kerja yang lebih tinggi.

Pandangan Munch konsisten dengan Geishecker et al. (2012) yang menyatakan bahwa (1) kehadiran outsourcing memiliki efek lebih negatif pada kesejahteraan karyawan jika didorong oleh pengurangan biaya tenaga kerja dan bukan dengan membuka pasar baru untuk produk dan jasa perusahaan, yang jauh lebih menguntungkan perusahaan dan tenaga kerja dalam jangka panjang, (2) efek outsourcing juga dapat bervariasi secara signifikan antara berbagai jenis karyawan karena penyesuaian tersebut tidak mempengaruhi semua karyawan.

Beberapa karyawan dapat mengambil manfaat dari proses tersebut, sedangkan yang lain mungkin mengalami kerugian. Sebagai contoh, pekerja yang berpengetahuan dapat mengambil manfaat proporsional dari outsourcing karena menciptakan kesempatan bagi mereka untuk memanfaatkan keahlian mereka yang sangat berguna ketika peluang kerja muncul dikemudian hari. 


\section{METODE PENELITIAN}

Penelitian ini dirancang untuk pengaruh kompensasi finansial dan nonfinansial terhadap kinerja karyawan dilaksanakan di Mesastila Hotels \& Resorts Magelang. Data penelitian termasuk data interval bersumber dari responden (karyawan Mesastila Hotels \& Resorts) 50 orang. Karyawan tetap 39 orang dan karyawan kontrak 11 orang yang dikumpulkan dengan kuesioner yang terdiri dari dua bagian. Pertama, pertanyaan/pernyataan untuk menemukan karakteristik demografis karyawan hotel. Kedua, adalah pernyataan untuk kompensasi finansial 12 item, nonfinansial 12 item dan kinerja karyawan hotel 12 item yang diukur dengan mengunakan skala likert (lima point: $1=$ sangat tidak setuju, $2=$ tidak setuju, $3=$ ragu-ragu, $4=$ setuju dan $5=$ sangat setuju) untuk mengukur produktivitas kerja (labor productivity) sesuai potensi dan frekuensi kegiatan perusahaan (Rangkuti, 2002). Uji validitas item kuesioner menggunakan Corrected Item-Total Correlation dan Cronbach's Alpha untuk uji reliabilitas. Untuk menjelaskan proporsi relatif kompensasi finansial dan nonfinansial dalam meningkatkan kinerja karyawan dalam penelitian ini, peneliti menggunakan analisis infrensial.

\section{HASIL DAN PEMBAHASAN Hasil Uji Instrumen}

Tabel 1 menunjukkan bahwa (1) Validitas item kompensasi finansial menunjukkan 11 item signifikan pada tingkat singnifikansi 5\% ( $\alpha 0.05)$ - kriteria yang sama berlaku juga dalam uji reliabilitas kompensasi finansial. Dengan demikian bahwa kompensasi finansial standar uji validitas dan reliabilitas. Khusus item 3 kompensasi finansial tidak valid yang kemudian dilakukan perbaikan pada redaksi pertanyaan. (2) Dengan cara yang sama dilakukan pada item kompensasi nonfinasial, oleh karena itu kuesioner kompensasi nonfinasial dinyatakan valid dan reliabel. (3) Demikian juga pada kuesioner kinerja karyawan menunjukkan 10 item dinyatakan valid dan dua item 7 dan 12 tidak valid yang selanjutnya direvisi/dilakukan perbaikan pada redaksi kalimat. Sementara uji reliabilitas kuesiner ini juga memenuhi standar keandalan

\begin{tabular}{|c|c|c|c|c|c|c|}
\hline \multirow{2}{*}{ Item } & \multicolumn{2}{|c|}{ Kompensasi Finansial } & \multicolumn{2}{|c|}{ Kompensasi Nonfinasial } & \multicolumn{2}{|c|}{ Kinerja Karyawan } \\
\hline & Validitas & Riliablitas & Validitas & Reliabilitas & Validitas & Reliabilitas \\
\hline 1 & 0.525 & \multirow{12}{*}{0.720} & 0.542 & \multirow{12}{*}{0.797} & 0.657 & \multirow{12}{*}{0.804} \\
\hline 2 & 0.430 & & 0.581 & & 0.598 & \\
\hline 3 & 0.051 & & 0.613 & & 0.707 & \\
\hline 4 & 0.360 & & 0.448 & & 0.675 & \\
\hline 5 & 0.395 & & 0.327 & & 0.240 & \\
\hline 6 & 0.404 & & 0.418 & & 0.326 & \\
\hline 7 & 0.344 & & 0.546 & & 0.068 & \\
\hline 8 & 0.272 & & 0.237 & & 0.230 & \\
\hline 9 & 0.480 & & 0.351 & & 0.734 & \\
\hline 10 & 0.429 & & 0.294 & & 0.675 & \\
\hline 11 & 0.330 & & 0.471 & & 0.613 & \\
\hline 12 & 0.229 & & 0.519 & & 0.110 & \\
\hline
\end{tabular}

Setelah dilakukan perbaikan pada masingmasing item yang tidak valid, maka semua item kompensasi finansial, kompensasi nonfinasial, kinerja karyawan dapat digunakan sebagai instrumen dalam mengumpulkan data penelitian ini.

\section{Hasil Uji Kelayakan Variabel}


Hasil uji kelayakan variabel ini pada dasarnya merupakan uji persyaratan untuk menentukan apakah analisis infrensial (dalam riset ini adalah analisis regresi) dapat digunakan atau tidak. Uji kelayakan minimal adalah uji normalitas, uji multikolinieritas dan uji homoginitas, sasilnya seperti dalam tabel 2 dapat dijelaskan sebagai berikut :

1. Koefisien $X^{2}$ kinerja karyawan sebesar 110.160 dengan $d f \quad 12$ pada taraf signifikansi 0,05 ini berarti bahwa kinerja karyawan mengikuti distribusi normal, dengan demikian asumsi normalitas penelitian ini terpenuhi.
2. Koefisien Durbin-Watson di peroleh $\mathrm{Dw}_{\mathrm{o}} 1,4625<1,94>1,6283$ dengan demikian bahwa pada setiap variabel bebas tidak terjadi autokorelasi

3. Koefisien multikuliner di peroleh VIF $\mathrm{X} 1<10$, nilai toleransi $<5, \mathrm{X} 2<10$ dan nilai toleransi $<5$ dengan demikian tidak terjadi multikuliner antar variabel bebas.

4. Koefisien homogenitas dalam semua kasus menunjukkan $p<0.05$, artinya bahwa dalam tiga variabel yang diuji memiliki nilai yang tidak sama, dengan demikian tidak terjadi homogenitas dalam semua variabel

Tabel 2

Hasil Uji Kelayakan Variabel

\begin{tabular}{|c|c|c|c|c|c|c|c|c|}
\hline \multirow{2}{*}{\multicolumn{2}{|c|}{$\begin{array}{l}\text { Uji Normalitas } \\
\text { Kinerja } \\
\text { Karyawan }\end{array}$}} & \multirow{3}{*}{$\begin{array}{c}\text { Uji Autokorelasi - } \\
\text { Durbin-Watson } \\
1.94\end{array}$} & \multicolumn{3}{|c|}{ Uji Multikolinieritas } & \multirow{2}{*}{\multicolumn{2}{|c|}{ Levene Statistic }} & \multirow{3}{*}{$\begin{array}{l}\text { Sig. } \\
.523\end{array}$} \\
\hline & & & \multirow[b]{2}{*}{$\mathrm{X} 1$} & \multirow{2}{*}{$\begin{array}{c}\text { Tolerance } \\
0.075\end{array}$} & \multirow{2}{*}{$\frac{\text { VIF }}{4.491}$} & & & \\
\hline 2 & 110.16 & & & & & $\mathrm{X} 1$ & 0.413 & \\
\hline df & 12 & 2 & $\mathrm{X} 2$ & 0.091 & 4.357 & $\mathrm{X} 2$ & 0.001 & .978 \\
\hline Sig. & 0 & $\mathrm{dL}<\mathrm{DW}>\mathrm{dU}$ & & & & $\mathrm{Y}$ & 0.185 & .669 \\
\hline \multicolumn{2}{|c|}{$\begin{array}{l}\text { Mengikuti } \\
\text { distribusi normal }\end{array}$} & $\begin{array}{c}1.46<1.94>1.62 \\
\text { Tidak terjadi } \\
\text { autokorelasi }\end{array}$ & \multicolumn{3}{|c|}{$\begin{array}{l}\text { Tidak terjadi multikolinieritas } \\
\text { antar variabel bebas }\end{array}$} & \multicolumn{3}{|c|}{$\begin{array}{l}\text { nilai signifikansi }<0.05 \text { - Tidak } \\
\text { terjadi hominitas }\end{array}$} \\
\hline
\end{tabular}

Tabel 2 menunjukkan bahwa :

Dengan terpenuhinya semua persyaratan analisis yang dipersyaratkan dalam penggunaan analisis regresi maka model analisis regresi berganda dalam penelitian ini dapat digunakan.

\begin{tabular}{|c|c|c|c|c|c|c|c|c|}
\hline & & Has & $\begin{array}{c}\text { Tabel } 3 \\
\text { Analisis } \mathrm{F}\end{array}$ & gres & & & & \\
\hline Model & $\mathrm{R}$ & ARS & SEE & df & $\mathrm{N}$ & Mean & $\mathrm{F}$ & Sig. \\
\hline Regression & $.751^{\mathrm{a}}$ & .701 & 1.50318 & 2 & 47 & 20.48 & 223.558 & $.000^{\mathrm{b}}$ \\
\hline \multirow[t]{2}{*}{ Kinerja Karyawan } & & & & & 39 & 20.61 & 3.146 & .034 \\
\hline & & & & & 11 & 20.00 & & \\
\hline
\end{tabular}

Hasil Uji Inferensial

\section{Uji R, Uji Simultan, Kontribusi Efektif} dan Uji Beda

Tabel 3 memperlihatkan kekuatan hubungan variabel, diterminasi efektif, pengaruh simultan dan uji beda konpensasi non finansial dan konpensasi finansial dengan kinerja karyawan.
Tabel 3 diatas menunjukkan bahwa :

1. Hubungan konpensasi non finansial dan konpensasi finansial dengan kinerja karyawan dijelaskan oleh $\boldsymbol{R} \quad \boldsymbol{0 . 7 5 1}$ dengan standard error of the estimate $(\mathrm{SEE})=1.505$ (kurang dari dua). Dengan demikian ikatan antara konpensasi finansial dan konpensasi non finansial dengan kinerja karyawan sangat kuat. Artinya bahwa tinggi rendahnya kinerja karyawan tidak bisa lepas dari tinggi rendahnya konpensasi finansial dan kompensasi non finansial yang mereka peroleh ditempat mereka bekerja. 
2. Kompensasi finansial dan konpensasi non finansial secara bersama-sama berpengaruh positif dan sangat signifikan terhadap kinerja karyawan. $\boldsymbol{F}$ 223.558, $p<0.01$. Artinya bahwa upaya meningkatkan kinerja karyawan harus dilakukan secara bersama-sama antara konpensasi finansial dan konpensasi nonfinansial. Mengabaikan salah satu (misalnya konpensasi finansial) dan memprioritaskan sisi lainnya (misalnya konpensasi non finansial) atau sebaliknya akan berpengaruh buruk pada kinerja karyawan.

3. Koefisien determinasi atau efektifitas pengaruh konpensasi finansial dan konpensasi nonfinansial terhadap kinerja karyawan dijelaskan oleh nilai Adjusted $\boldsymbol{R}$ Square (ARS) sebesar 0.701. Dengan demikian diterminasi atau sumbangan efektif konpensasi finansial dan konpensasi nonfinansial terhadap kinerja karyawan sebesar $\mathbf{7 0 . 1 \%}$, sisanya $29 \%$ dijelaskan oleh variabel lain diluar penelitian ini, misalnya teknologi dan gaya kepemimpinan.

4. Analisis kovarian menunjukkan perbedaan yang signifikan antara kinerja karyawan tetap dan karyawan kontrak, $\boldsymbol{F}$ $=3.146, p>0.05$. Perbedaan ini menunjukkan bahwa kinerja karyawan tetap (rerata $=$ 20.61) lebih baik dibanding karyawan kontrak (rerata = 20.00). Hal ini mungkin sangat logis karena dua alasan.

a. Karyawan tetap berjumlah 39 (78,0\%) akan selalu berhadapan dengan penilaian kinerja untuk kepentingan dan keberlanjutan karier mereka, sementara karyawan kontrak (11 atau 22,0\%) hanya menunggu habisnya masa kontrak dan kelanjutan kontrak itu belum diketahui.

b. Karyawan tetap selalu berhubungan dengan sangsi penundaan kenaikan jabatan atau penurunan jabatan atau penurunan gaji yang dikaitkan dengan penilaian kinerja mereka, sementara karyawan kontrak tidak terbebani dengan masalah ini.

\section{Uji Parsial}

Tabel 4 menunjukkan bagaimana kekuatan variabel bebas mengubah variabel terikat dalam kondisi ceteris paribus.

1. Konstanta

Dalam kondisi konstan nilai koefisien $\beta$ $=-3.718, S E 1.373, p>0.05$. Artinya jika kompensasi finansial dan kompensasi nonfinansial tidak ada kinerja karyawan akan turun sebesar 3.718 $x$ 0.751. makna penting dari konstanta ini adalah dalam jangka panjang terbukti :

a. Kompensasi finansial dan kompensasi nonfinansial menjadi faktor penentu bagi penurunan kinerja karyawan.

b. Mengabaikan kompensasi finansial dan kompensasi nonfinansial, maka manajer siap-siap saja untuk menyaksikan penurunan kinerja karyawan dan kinerja bisnis secara keseluruhan. 
Tabel 4

Hasil uji t

\begin{tabular}{|c|c|c|c|c|c|c|}
\hline & & $\begin{array}{r}\text { Unstande } \\
\text { Coeff }\end{array}$ & $\begin{array}{l}\text { rdized } \\
\text { cients }\end{array}$ & $\begin{array}{l}\text { Standardized } \\
\text { Coefficients }\end{array}$ & $\mathrm{t}$ & Sig. \\
\hline & & $\beta$ & Std. Error & Beta & & \\
\hline 1 & (Constant) & -3.718 & 1.373 & & -2.708 & .009 \\
\hline & Konpensasi Finansial & .544 & .107 & .533 & 5.098 & .000 \\
\hline & Konpensasi Non Finansial & .462 & .109 & .442 & 4.235 & .000 \\
\hline
\end{tabular}

2. Kompensasi Finansial

a. Koefisien regresi kompensasi finansial $\beta=0.544, S E=0.107 \mathrm{ini}$ menunjukan bahwa dalam jangka panjang terjadi penambahan konpensasi finansial sebesar $\mathrm{Rp}$ 1,akan meningkatkan kinerja karyawan sebesar 0.544 perbulan.

b. Pada saat riset ini dilakukan nilai konpensasi finansial ditemukan; $\boldsymbol{\beta}=$ $0.533, t 5.098, p>0.05$, ini berarti konpensasi finansial berpengaruh positif dan signifikan terhadap kinerja karyawan. Sepanjang variable lainnya dalam kondisi ceteris paribus.

3. Konpensasi Nonfinansial

a. Koefisien regresi konpensasi nonfinansial $\beta=0.462, S E 0.109$, ini berarti bahwa setiap satu perbaikan pada konpensasi nonfinansial dalam jangka panjang akan meningkatkan kinerja karyawan sebesar 0.462 perbulan.

b. Pada saat penelitian ini dilakukan, nilai konpensasi non finansial ditemukan; $\beta=0.442, t$ 4.235, $\boldsymbol{p}$ > 0.05, ini berarti konpensasi nonfinansial berpengaruh positif dan signifikan terhadap kinerja karyawan. Sepanjang variable lainnya dalam kondisi ceteris paribus.

\section{HASIL DAN PEMBAHASAN}

1. Hasil penelitian ini menunjukkan bahwa variabel kompensasi finansial memberikan pengaruh yang signifikan terhadap peningkatan kinerja karyawan
Mesastila Hotels \& Resorts. Kompensasi dimaknai sebagai imbalan jasa atau balas jasa yang diberikan oleh seseorang kepada orang lain (karyawan) karena telah menyelesaikan/melakukan pekerjaan tertentu. Hal yang sama juga berlaku dalam dunia bisnis, perusahaan akan memberikan imbalan baik dalam bentuk uang (finansial) maupun dalam bentuk tidak langsung (nonfinansial) kepada karyawannya, terutama karena karyawannya telah memberikan kontribusi berupa tenaga, waktu dan pikiran untuk mencapai tujuan dan kemajuan Mesastila Hotels \& Resorts secara keseluruhan.

2. Hasil analisis regresi menunjukkan bahwa variabel kompensasi finansial dan kompensasi nonfinansial berpengaruh signifikan terhadap kinerja karyawan Mesastila Hotels \& Resortsi karena di sebabkan oleh pihak Mesastila Hotels dan Resort memberikan imbalan baik dalam bentuk uang (finansial) maupun dalam bentuk tidak langsung (nonfinansial) kepada karyawannya.

3. Pada uji simultan diketahui bahwa kompensasi finansial dan kompensasi nonfinansial berpengaruh signifikan secara bersama-sama terhadap kinerja karyawan Mesastila Hotels dan Resort.

4. Hasil uji parsial penelitian ini digunakan untuk dapat menjawab hipotesis penelitian. Penelitian ini memiliki dua hipotesis, yaitu kompensasi finansial dan kompensasi nonfinansial berpengaruh signifikan terhadap kinerja karyawan 
Mesastila Hotels \& Resorts. Pengujian ini menunjukkan bahwa variabel kompensasi finansial dan kompensasi nonfinansial berpengaruh signifikan terhadap kinerja karyawan Mesastila Hotels \& Resorts, hal ini ditunjukkan dengan adanya stimulasi berupa gagasan/ide, lingkungan kerja yang kondusif dan komunikasi yang baik antara bawahan dan atasan, sehingga apa yang dikomunikasikan dapat dipahami dan dimengerti, sehingga tugas para karyawan dilaksanakan dengan sebaik mungkin sesuai dengan apa yang diharapkan oleh Mesastila Hotels \& Resorts.

5. Sedangkan partisipasi kerja yang merupakan keterlibatan karyawan dalam pekerjaan atau tugas baik pikiran, perasaan, mental, maupun emosional terhadap tanggung jawab yang diembannya juga meningkatkan komitmen kerja karyawan Mesastila Hotels \& Resorts. Selain itu, semakin tinggi tingkat kesejahteraan karyawan Mesastila Hotels \& Resorts maka semakin baik pula etos kerja karyawan Mesastila Hotels \& Resorts.

6. Berdasarkan Uji beda antara variabel bebas dan variabel terikat berdasarkan status karyawan bahwa memiliki perbedan dari masing-masing indikator variabel di antaranya adalah:

a. Jika seorang karyawan dengan gaji yang tinggi maka karyawan tersebut lebih loyal dalam menyelesaikan tanggung jawab yang di berikan dari seorang pimpinan organisasi .

Pemberian bonus terhadap seorang karyawan akan memiliki pengaruh positif terhadap kinerja karyawan, karena dengan pemberian bonus tersebut karyawan merasa di hargai pekerjaannya oleh organisasi.

c. Dalam organisasi kompensasi finansial menjadi salah satu alasan seseorang karyawan untuk memenuhi kebutuhan hidupnya, oleh karena itu karyawan akan bekerja secara maksimal jikalau pihak organisasi memenuhi apa yang di inginkan oleh karyawan berupa kompensasi finansial.

d. Semakin baik pekerjaan karyawan tergantung pada pemberian dan pembagian tugas yang di emban oleh karyawan tersebut, jikalau karyawan memiliki beban kerja melebihi tupoksi yang di bebankan maka karyawan tersebut akan mengalami kesulitan dalam menyelesaikan tugas, oleh karena itu karyawan harus di berikan beban kerja sesuai dengan kemampuan, agar karyawan tersebut dapat menyelesaikan pekerjaannya dengan baik.

e. Lingkungan kerja adalah salah satu penentu kenyamanan bagi karyawan, oleh karena itu sebuah organisasi harus memiliki, menyediakan lingkungan kerja yang kondusif agar para karyawan nyaman dalam bekerja.

f. Kompensasi non finansial serbagai faktor utama menghasilkan pengaruh yang kuat terhadap kinerja di antaranya adalah membentuk karakteristik kepemimpinan para karyawan dan menciptakan kondisi oraganisasi yang kondusif untuk meningkatkan kinerja karyawan

g. Kuantitas adalah suatu indikator untuk mencapai kepentingan sebuah organisasi, mengapa demikian, karena jika sebuah oraganisasi memiliki kuantitas sumberdaya yang mendukung maka kepentingan organisasi akan terlaksana dengan baik.

h. Kinerja karyawan tergantung pada seberapa besar pimpinan organisasi memberikan perhatian terhadap karyawan, karena karyawan adalah salah satu elemen kunci keberhasilan sebuah organisasi, oleh karena itu pihak organisasi perlu memberi perhatian 
terhadap karyawan agar karyawan memiliki kinerja yang baik.

\section{KESIMPULAN DAN REKOMENDASI}

Kompensasi finansial berpengaruh signifikan terhadap kinerja karyawan. Karena suatu imbalan yang baik dalam bentuk sejumlah uang (finansial)) kepada karyawan akan sangat membantu terciptanya lingkungan kerja yang kondusif dan komunikasi yang baik antara bawahan dan atasan.

Kompensasi nonfinansial juga berpengaruh secara signifikan terhadap kinerja karyawan, karena hal tersebut memberikan imbal balik dalam bentuk tidak langsung (nonfinansial) kepada karyawannya. Hal tersebut akan terlihat karena sikap seseorang dapat mencerminkan seberapa besar karyawan mengenal dan terikat pada organisasinya. Ketika seorang karyawan memiliki komitmen tinggi akan merasa bangga merasakan dirinya sebagai bagian dari suatu organisasi. Dengan kata lain, sikap yang merefleksikan loyalitas karyawan pada organisasi dan proses berkelanjutan di mana anggota organisasi mengekspresikan perhatiannya terhadap organisasi dan keberhasilan serta kemajuan yang berkelanjutan.

Bahwa Kompensasi finansial dan kompensasi nonfinansial berpengaruh simultan terhadap kinerja karyawan. Variabel yang sangat dominan pengaruhnya terhadap kinerja karyawan adalah kompensasi finansial.

Kontribusi efektif variabel bebas (kompensasi finansial) dan variabel terikat (kompensasi nonfinansial) adalah 70.1\%,. Selain itu status karyawan memberikan perbedaan penting pada tingkat kinerja karyawan, mungkin karena karyawan tetap memiliki kepentingan dengan keberlanjutan karier mereka maka kinerja mereka lebih baik dari karyawan kontrak.

Penelitian ini menunjukan bahwa kompensasi finansial dan nonfinansial berpengaruh positif dan signifikan terhadap kinerja karyawan, ini memberikan kesempatan kepada manajemen dalam melakukan kontrol dengan baik agar kinerja karyawan tetap dapat dipertahankan sesuai dengan harapan manajemen Mesastila Hotels \& Resorts.

\section{Keterbatasan riset}

Pertama, riset ini hanya membedakan kinerja berdasarkan status karyawan tetap dan kontrak, oleh karena itu untuk memastikan dominasi pengaruh kompensasi finansial dan nonfinansial, riset mendatang dapat digunakan untuk mengevaluasi jenis penghargaan mana yang berperan lebih dalam membangun kinerja karyawan Mesastila Hotels \& Resorts.

Kedua, tingkat kepekaan dan kekhawatiran responden dalam mengisi semua item kuesioner, terutama karena adanya persespsi penilaian dari atasan tentang loyalitas organisasi, sehingga informasi yang sangat berharga terkait konpensasi finansial maupun non finansial tidak diungkapkan dengan apa adanya.

Ketiga, sampel penelitian ini sangat kecil; (39 karyawan tetap dan 11 karyawan kontrak), oleh karena itu hasilnya tidak dapat digunakan dalam kontek yang lebih luas. Untuk itu validasi dimasa mendatang, riset yang sama dapat dilakukan dengan jumlah responden atau sampel yang lebih besar (dari beberapa hotel), dengan demikian hasilnya dapat digunakan sebagai generalisasi empiris yang lebih luas.

\section{REFERENSI}

Ali, R., \& Ahmed, M. S. 2009. The impact of reward and recognition programs on employee's motivation and satisfaction: an empirical study. International Review of Business Research Papers, 5(4), 270-279.

Almutairi, Obaid, Dhaifallah., Moradi, Ebrahim. Idrus, Durrishah, Emami, Raheleh and Alanazi, Talal, Ratyan. 2013. Job Satisfaction and Job Performance: A Case Study of FiveStar Hotels. World Journal of Social Sciences. 3(1). 27-37.

Caliskan, Esra, Nemli. 2010. The Impact of Strategic Human Resource 
Management on Organizational Performance. Journal of Naval Science and Engineering. 6(2), 100116.

Fatai Abiodun Atanda, Taiwo Olufemi Asaolu1 and Adewale Atanda Oyerinde, 2013. The Causality between Employees' Economic Rewards and Sustainable Performance Manufacturing Firms. International Journal of Business and Management; 8(24), 25-36.

Geishecker, Ingo, Maximilian Riedl, and Paul Frijters. 2012. "Offshoring and Job Loss Fears: An Econometric Analysis of Individual Perceptions." Labour Economics 19(10), 738-747.

Gohari, Payam. Kamkar Ali, Hosseinipour, S.J, Zohoori, Mahmood. 2013. Relationship Between Rewards and Employee Performance: A Mediating Role of Job Satisfaction. Interdisciplinary Journal of Contemporary Research in Business. 5(3), 571-597.

Hameed, A and Waheed. 2011. Employee Development and Its Affect on Employee Performance : A Conceptual Framework. International Journal of Business and Social Science. 2/13, pp $224-229$.

Iveta, Gabcanova, 2012. Human Resources Key Performance Indicators. Journal of Competitivenes 4(1), 117-128.

Monil, Muzalifah dan Tahir, Izah, Mohd. 2011. Determinants of Job Performance in Frontline Hotel Employees in Malaysia Using Structural Equation Model: A Proposed Conceptual Framework. International Journal of Business and Behavioral Sciences. 1(1) 32-42.

Munch, Jakob R. 2010. Whose Job Goes Abroad: International Outsourcing and Individual Job Separations. Journal of Economics. 11(2), 339-360.

Mutua, Shedrack, Mbithi., Karanja, Kabare., Namusonge, G.S. 2013. Role of Human Resource Management Practices on Performance of Financial
Cooperatives Based. International Journal of Education and Research, 12(1), 1-10.

Rangkuti, Freddy. 2002. Riset Pemasaran. 5, Jakarta: PT. Gramedia Pustaka Utama

Said, Kingira and Mescib, Muammer, 2010. Factors That Affect Hotel Employees Motivation The Case of Bodrum. Serbian Journal of Management. 5(1), $59-76$.

Sajuyigbe, A. S., Bosede . Olaoye and Adeyemi M.A, 2013. Impact of Reward on Employees Performance in a Selected Manufacturing Companies.International Journal of Arts and Commerce 2(2), 27 -32.

Sopiah. 2013. The Effect of Compensation toward Job Satisfaction and Job Performance of Outsourcing Employees. International Journal of Learning \& Development. 3(2), 77-91.

Sultana, Afshan. Irum, Sobia. Ahmed, Kamran and Mehmood, Nasir. 2012. Impact Of Training on Employee Performance. Interdisciplinary Journal of Contemporary Research in Business. 4(6). 646-661.

Sunil Panwar and Nitin Gupta. 2012. Money: Does It Really Affect Hotel Employee's Performance As A Motivational Factor. International Journal of Business \& Management Research. 2(2), 38-46

Voorde, Van De, Paauwe K. J., Van Veldhoven, M., 2010. Predicting Business Unit Performance Using Employee Surveys: Monitoring HRMRelated Changes, Human Resource Management Journal, 20(1). 44-63.

Wiese M. and Coetzee, R. 2013. The importance of non-financial motivators to pharmaceutical sales representatives: A demographic study. Southern African Business Review. 17(1). 2356. 